\title{
Social democrats and the new partisan politics of public investment in education
}

\author{
Marius R. Busemeyer
}

\begin{abstract}
This paper studies the impact on public education spending of social democratic participation in government. By means of a pooled time-series analysis of spending in OECD democracies, it is shown that social democrats have increased public spending primarily on higher education. This finding is at odds with simple class-based models of partisan preferences (Boix) that predict a preference for non-tertiary education. As an alternative, the notion of a 'new politics of public investment in education' (Iversen) is presented. From this perspective, political parties are not merely transmission belts for the economic interests of social classes, but use policies and spending strategically to attract and consolidate voter groups. By increasing public investment in tertiary education, social democrats cater to their core electoral constituencies (for example, by expanding enrolment) and, at the same time, new middle-class constituencies to escape electoral dilemmas and reforge the cross-class alliance with the middle class.
\end{abstract}

KEY WORDS Education; higher education; OECD countries; pooled time-series analysis; public spending; social democratic parties.

\section{INTRODUCTION}

What is the impact of social democratic government parties on public investment in education? Why should social democrats be interested in expanding public education in the first place? Are social democrats driven and constrained by external forces such as globalization or is there room for independent action? Can we observe differences in the dynamics of spending across educational sectors?

In seeking to answer these questions, this article makes both an empirical and a theoretical contribution. The empirical contribution comprises a comprehensive study of the impact of partisan factors on different types of education spending (total as well as sectoral). Despite the recent scholarly interest in the political economy of skill formation (Iversen and Soskice 2001; Iversen 2005; Thelen 2004), the study of the dynamics and determinants of education spending has been relatively neglected (notable exceptions are Castles 1982, 1989, 1998; Schmidt 2002, 2007; Busemeyer 2007). In the political economy literature, the most significant contribution is Boix $(1997,1998)$. His insight (building on Garrett and Lange 1991 and others) was that, in an era of economic 
internationalization, public investments in human capital formation have become a popular supply side-oriented policy instrument for social democratic parties. Owing to data limitations at the time, Boix did not test his argument with data on sectoral education spending (higher education vs. primary and secondary education).

The theoretical contribution of this paper is an alternative explanatory approach to the Boix model. Empirically, this paper shows that social democratic parties have primarily pursued a strategy of increased investment in public higher education, in association with an expansion of university enrolment. From the purely class-based perspective of the Boix model, this empirical finding is hard to explain, because it is not apparent why social democrats should increase spending in higher education - a policy area with limited redistributive capacity - instead of other social policies with a stronger redistributive component. In contrast, the notion of a 'new partisan politics of public investment in education' (inspired by Iversen 2006a: 5) is put forward. This thesis holds that social democratic parties are not simple transmission belts for the economic interests of lower income classes, but try to appeal to their core constituency (by expanding enrolment) while at the same time reaching out to new middle-class constituencies.

The paper proceeds as follows: section 2 anchors the theoretical approach in the literature (partisan theory, power resources theory) and discusses the state of research on education spending. At the end of section 2, the notion of a 'new partisan politics of public investment in education' is presented, along with testable hypotheses. Section 3 contains an empirical analysis of the impact of partisan forces on total and sectoral education spending (that is, higher education, primary and secondary education). Section 4 summarizes and concludes with remarks about the findings' implications for the further development of partisan theory.

\section{THEORY AND HYPOTHESES}

\subsection{Partisan theory and welfare state development}

Partisan theory emphasizes the importance of partisan factors in explaining welfare state development. It comes in two 'flavours': first, for power resources theory (for example, Stephens 1979; Esping-Andersen and Korpi 1984; EspingAndersen 1985; more recently, Hicks 1999; Huber and Stephens 2001; Bradley et al. 2003), economic classes build the fabric of society. The function of political parties is to mobilize these latent class interests and act as a 'transmission belt' for political demands. Second, partisan theory (or party difference theory see Hibbs 1977, 1987; Castles 1982; Schmidt 1982, 1996; Alt 1985; Chappell and Keech 1986) adopts a slightly different perspective. The theory is framed from the perspective of government parties and entails two claims: (1) Government parties matter: public policies are not shaped completely by exogenous forces (institutions, socio-economic factors), but the parties in power have an 
impact on policy output as well; (2) government parties of the left and of the right behave differently in government and pursue different policy programmes. This claim is posited against the 'partisan null hypothesis' of median voter models. The logic behind party differences is more 'political' than sociological, as in the case of power resources theory. Parties differ because they pursue policies 'in accordance with the objective economic interests and subjective preferences of their class-defined core political constituencies' (Hibbs 1987: 291) in order to be re-elected (Schmidt 1996: 156). Thus, political parties are not only 'transmission belts' for socio-political demands, but utilize policies to cater to and consolidate their respective bases.

The common element between power resources theory and party difference theory is the notion that partisan preferences can be derived from an inspection of the objective economic interests of classes or societal strata. The political struggle over public welfare is portrayed as a struggle over distribution (Huber and Stephens 2001: 17). In its simplest version, partisan theory assumes that leftist parties represent the interests of low income classes and thus favour more redistribution, for example, in the form of public spending, while rightist parties represent upper income classes who oppose public spending because they foot the tax bill.

\subsection{Partisan theory and education spending}

Studies on the determinants of education spending (Cameron and Hofferbert 1974; Verner 1979; Castles 1982, 1989, 1998; Schmidt 2002, 2007; Busemeyer 2006a, 2006b, 2007; Wolf 2006; Nikolai 2007) are mostly $y$-centred, that is, they have a generic, explorative approach to the study of education expenditure, with partisan factors being one important determinant among other socio-economic or institutional variables. Still, they often find a significant impact of government parties on education spending, with leftist parties spending more on education than rightist parties.

\section{Class-based approaches}

Political economy models of partisan preferences for education policies (Ansell 2006; Boix 1997, 1998; Garrett and Lange 1991; Garrett 1998) are rooted in power resources and partisan theories, that is, party strategies and preferences are derived from the objective economic interests of their assumed core electoral constituencies. The model developed by Boix $(1997,1998)$ provides clear expectations concerning why social democratic parties pursue strategies of increased investment in education. Processes of economic liberalization and internationalization are exogenous background factors that impact on the availability of strategies of macroeconomic policy such that Keynesian-style demand management becomes increasingly unfeasible (Boix 1998: 2-3). Thus, investments in human capital - that is, increasing the productivity of low-skilled workers - are a viable alternative approach 'to modify market outcomes and redistribute wealth to favour the least advantaged sectors and advance equality 
in general' (Boix 1998: 4). In contrast, conservative parties believe in the power of markets and want to maximize individual liberties (Boix 1998: 4). Consequently, the Boix model expects the government participation of social democrats to be associated with higher public spending on education, while conservatives in government are expected to reduce spending.

Boix $(1997,1998)$ tested his model on total education spending only, but he hinted at some ideas about the relative importance of sectoral education spending. In line with the notion of a class-based model of redistributive politics, Boix (1998: 37) makes the point that 'generic assets' imparted in the general school system are more important than various forms of post-secondary education. If the economic interests of the working class are taken as a point of departure, one could argue that vocational training (that is, non-tertiary post-secondary education) should be equally important for the core social democratic constituencies. Public investment in higher education, however, should not be a priority for leftist government parties. The expansion of publicly financed tertiary education primarily benefits the (upper) middle classes, not the working class. And even if the children of the working class manage to enter higher education, they will eventually end up in the higher income strata and so become members of the rightists' constituency. Thus, with regard to sectoral education spending, the Boix model predicts a positive association of social democratic government parties with spending on primary, secondary, and non-tertiary post-secondary education, but a negative one with spending on tertiary education (see also Ansell 2006).

\section{The new partisan politics of public investment in education}

The notion of what is here called 'the new partisan politics of public investment in education' (Iversen 2006a, 2006b) differs from purely class-based approaches on two points: first, following Cusack (1997) and Kitschelt (1994, 1999), I surmise that political parties are not simple transmission belts for the objectively definable economic interests of their constituencies. Instead, parties take into account public sentiments about various policy areas (Wlezien 1995, 2004) in order to attract new voter groups (primarily from the middle classes). Second, I posit that the process of educational expansion has not only impacted on the educational preferences of the median voter, but has also altered the preferences of left parties' core constituencies.

Before I elaborate on these ideas, it is important to point to the crucial importance of educational expansion as a background condition and driving force behind changing partisan and individual preferences for education policies. Educational expansion is a process of universalizing access to ever higher levels of education, spanning a large number of countries. In most industrialized countries, primary and secondary education became universalized in the post-war decades; educational expansion has continued in the area of higher (tertiary) education, but remaining differences between countries in terms of enrolment and spending are far more significant in the case of higher education than in that of primary and secondary education 
(UNESCO 2006; Busemeyer 2007). This leads to the expectation that partisan factors will contribute more to explaining the former.

More importantly, educational expansion impacts on the preferences of the median voter as well as the core constituents of left parties. A full-blown analysis of individual preferences for different types of education is beyond the scope of this article, but it can be expected that a side-product of educational expansion is the inflation of educational expectations both for the median voter and the core constituencies of left parties.

How are political parties, and social democratic parties in particular, coping with this popular will to expand higher education? A simple and purely classbased model predicts that social democrats will want to install a partially private higher education system (tuition fees combined with scholarship programmes for working-class children) instead of subsidizing the 'poor rich' (the middle class) through public higher education (Ansell 2006: 11). In contrast, I argue that political parties not only act as 'transmission belts' for economic class interests, but try to blend ideological preferences with a sensitivity to the preferences of the electorate (Cusack 1997; see also Wlezien 1995, 2004).

The challenge for social democratic parties is thus to cater for middle-class voter groups without alienating their core constituencies. The expansion of public tertiary education can become a means of reforging this cross-class alliance between the lower and the middle classes. High-quality public higher education is attractive to middle-class voters because, in comparison to private education, it reduces the price they have to pay for university education. For lower income classes, the improvement of access to higher education institutions is most important. Thus, a crucial precondition for the long-term success of the cross-class coalition is that the expansion of public education institutions takes place alongside efforts to open up enrolment and to reduce the class bias in university access (Iversen 2006a: 5). Over time, the opening up of access to higher education in previous years results in a self-reinforcing circle: working-class parents increasingly favour expanding public higher education institutions in order to send their children to universities, who in turn become supporters of the continuing expansion of public higher education.

In sum, while traditional class-based approaches expect social democrats to focus on 'generic assets' (Boix 1998: 37) and to favour a partially private higher education system (Ansell 2006), according to the hypothesis presented here, social democratic government participation is associated with increases in public spending on higher education. This can be explained only by taking into account the fact that political parties do not act as simple transmission belts for economic class interests, but use public policies to cater to new voting groups and to reforge cross-class alliances.

Despite this, it is important to keep in mind that the core claim of partisan theory ('parties matter') remains relevant. In our case, the difference between leftist and rightist parties is that the former favour the expansion of public authority in the education system, while the latter prefer private alternatives. The 
reason why social democrats prefer public higher education institutions is that in this case the decision on the expansion of access to higher education is not delegated to private institutions, but remains within the reach of public authority. It is also important to note that the strategy of expanding public education was used by social democratic government parties well before the 1990s (Schmidt 2007). But with the increasing internationalization of the economy, structural changes towards the service and knowledge economy, and the continuing process of educational expansion, the focus has shifted from secondary education and vocational training to higher education.

\subsection{Hypotheses}

Summing up the theoretical discussion, I shall test the following hypotheses empirically:

1. Total education spending.

Social democratic government participation is associated with increases in total public education spending, in particular when leftist government participation takes place alongside increasing trade openness (the Boix model).

2. Sectoral education spending.

2a. Social democratic government participation is associated with increases in public spending on primary, secondary, and non-tertiary post-secondary (PSNTPS) education, but decreases in higher education spending (extension of Boix model).

2b. Social democratic government participation is only weakly associated with spending on PSNTPS education, but positively associated with increases in public spending on tertiary education. Moreover, the expansion of spending is fuelled by partisan strategies in the domestic arena and thus is not related to changes in trade openness (extended and applied 'new politics of public investment in education' argument (Iversen)).

\section{EMPIRICAL ANALYSIS}

\subsection{Variables}

\section{Dependent variables}

The central dependent variables analysed here are total public education spending, public spending on PSNTPS education, as well as public spending on tertiary education (taken mainly from the Organization for Economic Cooperation and Development's (OECD's) Education at a Glance database). ${ }^{1}$ All spending variables are given as a percentage of gross domestic product (GDP) and cover public spending on educational institutions. ${ }^{2}$ The time period covered ranges from 1980 to 2002 in the case of total public education spending, and from 1991 to 2002 for sectoral education spending because reliable data on 
the latter (namely, public investment in higher education) have been available only since the 1990s (cf. Schmidt 2007). The analysis covers 21 OECD democracies. ${ }^{3}$ In addition to spending, we will take a brief look at tertiary enrolment as dependent variable to check whether the partisan effect of social democrats is mainly quantitative (expansion of enrolment and spending) or both qualitative and quantitative (expansion of spending on top of expansion of enrolment).

\section{Independent variables and controls}

The most important independent variable is, of course, the government participation of social democrats. The share of cabinet seats held by social democrats and various other party families in a given country-year is taken from Schmidt (2003).

Another important independent variable is exposure to the forces of economic globalization. In the Boix model, the internationalization of the economy is a background condition forcing social democrats to adapt new partisan strategies. But if there really is a connection between internationalization and social democrats' willingness to invest in education, we should expect a stronger reorientation towards human capital investment in those countries that are very open and governed by social democrats (interaction effect). In principle, if the Boix model is taken seriously, this interaction effect should hold regardless of the type of education spending. Alternatively, trade openness might impact on education spending independently of the partisan composition of governments (Ansell 2008; Crouch et al. 1999). As a measure for trade openness, the average of exports and imports as a percentage of GDP is used. ${ }^{4}$

The analyses also include a number of control variables. Demographic demand for education services is captured by an 'age' variable (i.e. the ratio between the population share of those aged 65 and above, and that of those aged 5 to 29). Female labour force participation is included because it can be expected to increase the demand for educational services, both in the PSNTPS and in the higher education sector. The level and change of economic well-being (gross national income (GNI) per capita) is included to capture the impact of fluctuations in the business cycle on changes in spending. A dummy for federal countries is included to control for the fact that federalism is generally ascribed a retarding effect on public spending (Obinger et al. 2005). Also, policy-making responsibilities for education are often delegated to lower levels of government in federal countries. Finally, I include the total level of public spending (as a percentage of GDP) and the level of gross public debt to model the budget constraint of spending decisions, which takes into account the fact that decisions about individual policy areas have to be considered within the context of changing budget conditions.

\subsection{Statistical methods}

Despite the frequent use and popularity of the framework of time-series crosssection analyses, a common and widely accepted methodological standard has 
yet to emerge, as evinced by current discussions in the relevant literature (Kittel and Winner 2005; Plümper et al. 2005; Plümper and Troeger 2007). The core hypotheses of this article were tested using a variety of model specifications. Owing to space constraints, I focus on the one specification that seems most advisable. Interested readers can find a full description of the statistical methods used as well as further empirical evidence and multiple robustness checks in the online Appendix. From a theoretical standpoint, we are interested in changes in spending as a result of changes in the partisan composition of governments. The preferred statistical method for testing this kind of hypothesis is an error-correction model (ECM) (Beck 1991; Iversen and Cusack 2000; Kaufman and Segura-Ubiergo 2001). Here, the dependent variable is given in changes (first differences) and the independent variables are included both as lagged levels $(t-1)$ and changes. The coefficients on the lagged levels of independent variables give an estimate of the permanent (long-term) effect of a change in this variable on the dependent variable, while the coefficients on the changes in these variables are an estimate of the transitory (short-term) effects of a change in the respective variable. As is customary, I use panel-corrected standard errors as advised by Beck and Katz (1995, 1996; Beck 2001).

\subsection{Findings}

\section{Government participation of social democrats}

The impact of the main independent variable of interest, the government participation of social democrats, varies considerably from one type of spending to another. From Table 1 it can be seen that the simple version of the Boix model (hypothesis 1) finds some, but not overwhelming, support. Government participation of social democrats has a positive and statistically significant impact on total public education spending in the long run, but a negative transitory impact (models 1 and 2 of online Table 2), independent of whether one looks at the longer time period (model 1) or only the 1990s (model 2). ${ }^{5}$ The long-term permanent impact of a change from a government with no social democrats to one consisting only of social democrats (for example, in Australia (1983), Greece (1981 and 1993), New Zealand (1984 and 1999), Norway (1986), Spain (1982), Sweden (1982 and 1994), the UK (1997)) is an increase in public education spending of 0.5 percentage points. ${ }^{6}$ This is about 10 per cent of the OECD average for public education spending for 2002.

When sectoral education spending is chosen as the dependent variable instead of total education spending, it becomes obvious that the relationship between partisanship and education spending is more complex than is assumed by the simple version of the Boix model.

When we look at the impact of leftist parties on primary, secondary, and postsecondary education spending (model 3), we find the expected positive association, although it is not statistically significant in all specifications (see the online Appendix). In addition, the positive association is mainly a long-term effect. According to the coefficient estimates of model 3, the long-term 
Table 1 The impact of government participation of social democrats on various types of education spending.

\begin{tabular}{|c|c|c|c|c|c|c|c|c|}
\hline \multirow[t]{2}{*}{ Dependent variable } & \multicolumn{2}{|c|}{$\begin{array}{l}\text { (1) } \\
\text { Public education } \\
\text { spending (\% of GDP), } \\
\text { first differences } \\
\text { (changes). }\end{array}$} & \multicolumn{2}{|c|}{$\begin{array}{l}\text { (3) } \\
\text { Public spending on } \\
\text { PSNTPS education } \\
\text { (\% of GDP), first } \\
\text { differences (changes) }\end{array}$} & \multicolumn{2}{|c|}{$\begin{array}{c}\text { (5) (6) } \\
\text { Public spending on } \\
\text { tertiary education (\% of } \\
\text { GDP), first differences } \\
\text { (changes) }\end{array}$} & \multicolumn{2}{|c|}{$\begin{array}{c}\text { (7) } \\
\text { Gross tertiary } \\
\text { enrolment, first } \\
\text { differences (changes) }\end{array}$} \\
\hline & $\begin{array}{c}1980- \\
2002\end{array}$ & $\begin{array}{c}1993- \\
2002\end{array}$ & $\begin{array}{c}1991- \\
2002\end{array}$ & $\begin{array}{c}1991- \\
2002\end{array}$ & $\begin{array}{c}1991- \\
2002\end{array}$ & $\begin{array}{c}1991- \\
2002\end{array}$ & $\begin{array}{c}1980- \\
1991\end{array}$ & $\begin{array}{c}1992- \\
2002\end{array}$ \\
\hline \multicolumn{9}{|c|}{ Lagged level dependent variables } \\
\hline $\begin{array}{l}\text { Public education spending, } \\
\text { lagged level }(t-1)\end{array}$ & $\begin{array}{l}-0.1423 \\
(6.73)^{* * *}\end{array}$ & $\begin{array}{l}-0.1431 \\
(3.26)^{* * *}\end{array}$ & & & & & & \\
\hline $\begin{array}{l}\text { Public spending on PSNTPS } \\
\text { education, lagged level } \\
\text { (t-1) }\end{array}$ & & & $\begin{array}{l}-0.2202 \\
(3.00)^{* * *}\end{array}$ & $\begin{array}{l}-0.2268 \\
(3.08)^{* * *}\end{array}$ & & & & \\
\hline $\begin{array}{l}\text { Public spending on tertiary } \\
\text { education, lagged level } \\
(t-1)\end{array}$ & & & & & $\begin{array}{l}-0.4321 \\
(3.41)^{* * *}\end{array}$ & $\begin{array}{l}-0.4422 \\
(3.38)^{* * *}\end{array}$ & & \\
\hline $\begin{array}{l}\text { Gross tertiary enrolment, } \\
\text { lagged level }(t-1)\end{array}$ & & & & & & & $\begin{array}{r}-0.8259 \\
(2.49)^{* *}\end{array}$ & $\begin{array}{r}-0.0970 \\
(2.64)^{* * *}\end{array}$ \\
\hline \multicolumn{9}{|c|}{ Social democratic government participation and its interactions } \\
\hline $\begin{array}{l}\text { Cabinet share of social } \\
\text { democrats, lagged level } \\
(t-1)\end{array}$ & $\begin{array}{r}0.0007 \\
(2.19)^{* *}\end{array}$ & $\begin{array}{r}0.0010 \\
(2.19)^{* *}\end{array}$ & $\begin{array}{c}0.0013 \\
(3.43)^{* * *}\end{array}$ & $\begin{array}{l}-0.0010 \\
(0.66)\end{array}$ & $\begin{array}{l}0.0011 \\
(2.81)^{* * * *}\end{array}$ & $\begin{array}{l}0.0024 \\
(1.85)^{*}\end{array}$ & & \\
\hline $\begin{array}{l}\text { Cabinet share of social } \\
\text { democrats, change }(\Delta)\end{array}$ & $\begin{array}{l}-0.0013 \\
(1.93)^{*}\end{array}$ & $\begin{array}{l}-0.0006 \\
(0.51)\end{array}$ & $\begin{array}{l}0.0012 \\
(1.12)\end{array}$ & $\begin{array}{l}0.0013 \\
(1.27)\end{array}$ & $\begin{array}{l}0.0018 \\
(1.92)^{*}\end{array}$ & $\begin{array}{l}0.0017 \\
(1.79)^{*}\end{array}$ & $\begin{array}{l}-0.0068 \\
(0.09)\end{array}$ & $\begin{array}{l}-0.0037 \\
(0.29)\end{array}$ \\
\hline
\end{tabular}


Table 1 Continued

\begin{tabular}{|c|c|c|c|c|c|c|c|c|}
\hline \multirow{2}{*}{$\begin{array}{l}\text { Dependent variable } \\
\text { Time period }\end{array}$} & \multicolumn{2}{|c|}{$\begin{array}{l}\text { (1) } \\
\text { Public education } \\
\text { spending (\% of GDP), } \\
\text { first differences } \\
\text { (changes) }\end{array}$} & \multicolumn{2}{|c|}{$\begin{array}{l}\text { (3) } \\
\text { Public spending on } \\
\text { PSNTPS education } \\
\text { (\% of GDP), first } \\
\text { differences (changes) }\end{array}$} & \multicolumn{2}{|c|}{$\begin{array}{l}\text { (5) (6) } \\
\text { Public spending on } \\
\text { tertiary education (\% of } \\
\text { GDP), first differences } \\
\text { (changes) }\end{array}$} & \multicolumn{2}{|c|}{$\begin{array}{c}\text { (7) } \\
\text { Gross tertiary } \\
\text { enrolment, first } \\
\text { differences (changes) }\end{array}$} \\
\hline & $\begin{array}{c}1980- \\
2002\end{array}$ & $\begin{array}{c}1993- \\
2002\end{array}$ & $\begin{array}{c}1991- \\
2002\end{array}$ & $\begin{array}{c}1991- \\
2002\end{array}$ & $\begin{array}{c}1991- \\
2002\end{array}$ & $\begin{array}{c}1991- \\
2002\end{array}$ & $\begin{array}{c}1980- \\
1991\end{array}$ & $\begin{array}{c}1992- \\
2002\end{array}$ \\
\hline $\begin{array}{l}\text { Interaction: social } \\
\text { democrats and openness, } \\
\text { lagged level }(t-1)\end{array}$ & & & & $\begin{array}{l}0.7863 \\
(1.65)^{*}\end{array}$ & & $\begin{array}{l}-0.4348 \\
(1.14)\end{array}$ & & \\
\hline $\begin{array}{l}\text { Cabinet share of social } \\
\text { democrats (moving } \\
\text { average), lagged level } \\
(t-1)\end{array}$ & & & & & & & $\begin{array}{l}-0.0223 \\
(0.36)\end{array}$ & $\begin{array}{r}0.0273 \\
(2.10)^{* *}\end{array}$ \\
\hline \multicolumn{9}{|l|}{ Control variables } \\
\hline Age ratio, lagged level $(t-1)$ & $\begin{array}{l}-0.5526 \\
(3.30)^{k * *}\end{array}$ & $\begin{array}{l}-0.2081 \\
(1.28)\end{array}$ & $\begin{array}{l}-0.1605 \\
(0.93)\end{array}$ & $\begin{array}{l}-0.2475 \\
(1.25)\end{array}$ & $\begin{array}{l}-0.5169 \\
(1.76)^{*}\end{array}$ & $\begin{array}{c}-0.4882 \\
(1.72)^{*}\end{array}$ & $\begin{array}{c}-33.9769 \\
(0.54)\end{array}$ & $\begin{array}{l}-5.0268 \\
(0.90)\end{array}$ \\
\hline Age ratio, change $(\Delta)$ & $\begin{array}{l}2.0471 \\
(1.47)\end{array}$ & $\begin{array}{l}3.1475 \\
(1.59)\end{array}$ & $\begin{array}{l}-1.4596 \\
(0.59)\end{array}$ & $\begin{array}{l}-1.3235 \\
(0.55)\end{array}$ & $\begin{array}{l}-2.2090 \\
(1.57)\end{array}$ & $\begin{array}{l}-2.2971 \\
(1.60)\end{array}$ & $\begin{array}{l}29.1654 \\
(0.05)\end{array}$ & $\begin{array}{l}-2.9889 \\
(0.13)\end{array}$ \\
\hline $\begin{array}{l}\text { National income per capita, } \\
\text { lagged level (t-1) }\end{array}$ & $\begin{array}{l}0.0056 \\
(1.91)^{*}\end{array}$ & $\begin{array}{l}0.0068 \\
(1.23)\end{array}$ & $\begin{array}{l}0.0011 \\
(0.19)\end{array}$ & $\begin{array}{l}0.0011 \\
(0.19)\end{array}$ & $\begin{array}{l}0.0107 \\
(1.36)\end{array}$ & $\begin{array}{l}0.0109 \\
(1.40)\end{array}$ & $\begin{array}{l}1.0559 \\
(1.11)\end{array}$ & $\begin{array}{l}-0.1150 \\
(1.52)\end{array}$ \\
\hline $\begin{array}{l}\text { National income per capita, } \\
\text { change }(\Delta)\end{array}$ & $\begin{array}{c}-0.0605 \\
(2.60)^{* * *}\end{array}$ & $\begin{array}{l}-0.0799 \\
(2.62)^{* * *}\end{array}$ & $\begin{array}{l}-0.0625 \\
(1.91)^{*}\end{array}$ & $\begin{array}{c}-0.0631 \\
(1.94)^{*}\end{array}$ & $\begin{array}{l}-0.0381 \\
(0.91)\end{array}$ & $\begin{array}{c}-0.0378 \\
(0.90)\end{array}$ & $\begin{array}{l}-0.7417 \\
(0.17)\end{array}$ & $\begin{array}{l}0.5353 \\
(1.43)\end{array}$ \\
\hline $\begin{array}{l}\text { Female labour force } \\
\text { participation, lagged level } \\
(t-1)\end{array}$ & $\begin{array}{r}0.0050 \\
(2.55)^{* *}\end{array}$ & $\begin{array}{l}0.0073 \\
(1.82)^{*}\end{array}$ & $\begin{array}{c}0.0052 \\
(1.70)^{*}\end{array}$ & $\begin{array}{l}0.0040 \\
(1.36)\end{array}$ & $\begin{array}{c}0.0072 \\
(1.89)^{*}\end{array}$ & $\begin{array}{c}0.0082 \\
(1.80)^{*}\end{array}$ & $\begin{array}{l}0.1986 \\
(1.11)\end{array}$ & $\begin{array}{l}0.0481 \\
(1.43)\end{array}$ \\
\hline
\end{tabular}




\begin{tabular}{|c|c|c|c|c|c|c|c|c|}
\hline $\begin{array}{l}\text { Female labour force } \\
\text { participation, change }(\Delta)\end{array}$ & $\begin{array}{l}0.0010 \\
(0.11)\end{array}$ & $\begin{array}{l}0.0088 \\
(0.37)\end{array}$ & $\begin{array}{l}-0.0053 \\
(0.23)\end{array}$ & $\begin{array}{l}-0.0088 \\
(0.37)\end{array}$ & $\begin{array}{l}-0.0050 \\
(0.19)\end{array}$ & $\begin{array}{c}-0.0031 \\
(0.12)\end{array}$ & $\begin{array}{c}-1.4194 \\
(1.59)\end{array}$ & $\begin{array}{r}-0.6983 \\
(2.23)^{* *}\end{array}$ \\
\hline Federalism & $\begin{array}{c}-0.0220 \\
(0.69)\end{array}$ & $\begin{array}{l}-0.0467 \\
(0.95)\end{array}$ & $\begin{array}{l}-0.0175 \\
(0.64)\end{array}$ & $\begin{array}{l}-0.0240 \\
(0.88)\end{array}$ & $\begin{array}{l}-0.0020 \\
(0.06)\end{array}$ & $\begin{array}{l}0.0015 \\
(0.04)\end{array}$ & $\begin{array}{l}7.1761 \\
(0.93)\end{array}$ & $\begin{array}{l}-0.3952 \\
(0.51)\end{array}$ \\
\hline $\begin{array}{l}\text { Public spending, lagged } \\
\text { level }(t-1)\end{array}$ & $\begin{array}{c}0.0113 \\
(5.66)^{* * *}\end{array}$ & $\begin{array}{l}0.0094 \\
(2.95)^{* * *}\end{array}$ & $\begin{array}{l}0.0037 \\
(1.38)\end{array}$ & $\begin{array}{l}0.0035 \\
(1.33)\end{array}$ & $\begin{array}{r}0.0076 \\
(2.17)^{* *}\end{array}$ & $\begin{array}{r}0.0081 \\
(2.13)^{* *}\end{array}$ & & \\
\hline Public spending, change $(\Delta)$ & $\begin{array}{c}0.0436 \\
(5.16)^{* * *}\end{array}$ & $\begin{array}{r}0.0375 \\
(2.49)^{* *}\end{array}$ & $\begin{array}{l}0.0054 \\
(0.30)\end{array}$ & $\begin{array}{l}0.0054 \\
(0.31)\end{array}$ & $\begin{array}{l}-0.0020 \\
(0.10)\end{array}$ & $\begin{array}{l}-0.0018 \\
(0.09)\end{array}$ & & \\
\hline $\begin{array}{l}\text { Gross public debt, lagged } \\
\text { level }(t-1)\end{array}$ & $\begin{array}{l}-0.0015 \\
(4.92)^{* * *}\end{array}$ & $\begin{array}{l}-0.0014 \\
(4.16)^{* * *}\end{array}$ & $\begin{array}{l}-0.0015 \\
(3.45)^{* * *}\end{array}$ & $\begin{array}{l}-0.0020 \\
(3.01)^{* * *}\end{array}$ & $\begin{array}{l}-0.0004 \\
(0.83)\end{array}$ & $\begin{array}{c}-0.0002 \\
(0.27)\end{array}$ & & \\
\hline $\begin{array}{l}\text { Gross public debt, change } \\
(\Delta)\end{array}$ & $\begin{array}{l}0.0018 \\
(0.79)\end{array}$ & $\begin{array}{l}-0.0027 \\
(0.68)\end{array}$ & $\begin{array}{l}-0.0008 \\
(0.21)\end{array}$ & $\begin{array}{l}-0.0002 \\
(0.06)\end{array}$ & $\begin{array}{l}-0.0050 \\
(0.87)\end{array}$ & $\begin{array}{l}-0.0056 \\
(0.96)\end{array}$ & & \\
\hline $\begin{array}{l}\text { Trade openness, lagged } \\
\text { level }(t-1)\end{array}$ & $\begin{array}{l}0.0015 \\
(2.37)^{* *}\end{array}$ & $\begin{array}{l}0.0011 \\
(1.07)\end{array}$ & $\begin{array}{l}-0.0003 \\
(0.40)\end{array}$ & $\begin{array}{c}-0.0024 \\
(1.73)^{*}\end{array}$ & $\begin{array}{l}0.0011 \\
(1.04)\end{array}$ & $\begin{array}{c}0.0022 \\
(1.82)^{*}\end{array}$ & $\begin{array}{c}-0.0406 \\
(0.44)\end{array}$ & $\begin{array}{c}-0.0066 \\
(0.46)\end{array}$ \\
\hline Trade openness, change $(\Delta)$ & $\begin{array}{l}0.0020 \\
(0.38)\end{array}$ & $\begin{array}{l}0.0029 \\
(0.26)\end{array}$ & $\begin{array}{c}0.0184 \\
(1.85)^{*}\end{array}$ & $\begin{array}{r}0.0204 \\
(2.03)^{* *}\end{array}$ & $\begin{array}{r}0.0258 \\
(2.26)^{* *}\end{array}$ & $\begin{array}{r}0.0248 \\
(2.14)^{* *}\end{array}$ & $\begin{array}{l}0.4918 \\
(1.23)\end{array}$ & $\begin{array}{r}-0.2640 \\
(2.37)^{* *}\end{array}$ \\
\hline Constant & $\begin{array}{l}0.0903 \\
(1.36)\end{array}$ & $\begin{array}{c}-0.1392 \\
(1.20)\end{array}$ & $\begin{array}{r}0.4801 \\
(2.12)^{* *}\end{array}$ & $\begin{array}{c}0.7185 \\
(2.74)^{* * *}\end{array}$ & $\begin{array}{c}-0.3266 \\
(1.72)^{*}\end{array}$ & $\begin{array}{c}-0.4597 \\
(1.82)^{*}\end{array}$ & $\begin{array}{c}16.4739 \\
(2.41)^{* *}\end{array}$ & $\begin{array}{c}8.1004 \\
(2.84)^{* * *}\end{array}$ \\
\hline$R^{2}$ & 0.23 & 0.28 & 0.15 & 0.16 & 0.31 & 0.31 & 0.41 & 0.24 \\
\hline Observations & 390 & 188 & 201 & 201 & 202 & 202 & 223 & 210 \\
\hline Number of countries & 21 & 21 & 21 & 21 & 21 & 21 & 21 & 21 \\
\hline
\end{tabular}

Notes: $z$ statistics in parentheses; * significant at 10 per cent; ${ }^{* *}$ significant at 5 per cent; *** significant at 1 per cent. 
permanent effect of a transition from a government without social democratic participation to one with only social democrats is about 0.6 percentage points (with an OECD average of roughly 3.6 per cent of GDP). Thus, in comparison to the effect on total public education spending, the magnitude of the effect on PSNTPS education spending is larger (16.6 vs. 10 per cent of the OECD average).

Analysis of the determinants of public spending on higher education (model 5) reveals a more coherent finding, however. Here, we find a clearly positive association between the government participation of social democrats and spending. The positive association holds regardless of the model specification (see the online Appendix). More importantly, the positive effects of social democratic government participation show up both in the long term (permanent effect) and in the short term (transitory effect). Both coefficients have a positive sign and are statistically significant. The magnitude of the partisan effect is considerable: based on the coefficient estimates of model 5, the predicted long-term permanent impact of a change in government from one with no social democratic participation to one consisting only of social democrats is an increase in spending of 0.25 percentage points (with an OECD average of 1.1 per cent of GDP in 2002). The magnitude of the effect on higher education spending is larger (23 per cent) than in the case of PSNTPS spending (17 per cent) or total education spending (10 per cent).

In sum, a preliminary conclusion of the analysis is that the dynamics of education spending are complex. First, the relationship between leftist government parties and total education spending is somewhat inconclusive. Second, with regard to sectoral education spending, social democrats have preferred to increase spending on tertiary education to a greater extent than spending on primary and secondary education.

Trade openness and its interaction with social democratic government participation It was suggested above that trade openness is more than a diffuse background condition that can be held constant. The findings in Table 1 suggest that differences in trade exposure have important consequences for public investment in human capital formation, depending on the type of spending.

First, the direct association between trade openness and total education spending (see models 1 and 2 in Table 2) is not robust. The association between spending on PSNTPS education and trade openness is equally weak (models 3 and 4) and consistently fails to attain statistical significance. The strongest impact of trade openness on education spending, however, can be seen in the case of tertiary education. Here we find a positive and significant short-term impact, indicating that advances in economic internationalization are accompanied by increases in public investment in tertiary education. In sum, if there is evidence that economies open to international economic competition have increased public investment in education, it can be found primarily in the dynamics of higher education. 
What about the interaction between trade openness and the government participation of social democrats? Figure 1 contains plots of this interaction term and its effects on total public education spending (chart A), PSNTPS education spending (chart B), and tertiary education spending (chart $C) .^{7}$ The first chart in Figure 1 suggests that, for low levels of trade openness, the marginal effect of social democratic government participation on total education spending is actually negative. In line with the Boix argument, the effect becomes positive with higher levels of trade openness. But the 95 per cent confidence band almost always includes zero. Consequently, the interaction between trade openness and social democratic government participation fails to meet common standards of statistical significance in the case of total education spending.

A look at the dynamics of sectoral education spending might explain why there is no significant relationship on the aggregate level. Chart B shows that there is a strong interaction effect for the case of PSNTPS education spending. This finding is in line with the extended version of the Boix argument (hypothesis 2a): social democrats in government in open economies increase spending in non-tertiary education to cushion the impact of economic internationalization for their core electoral constituencies. However, the findings for the case of higher education (chart $\mathrm{C}$ ) show that, in addition to the Boix logic, another mechanism must be at work here. Chart $\mathrm{C}$ shows that the positive impact of social democratic government participation on public spending in tertiary education is completely independent of trade openness. The slope of the estimated marginal effect of social democrats stays virtually constant across the range of values for trade openness and the confidence interval includes zero almost all the time. Hence, the positive impact of social democratic government participation on higher education spending is independent of trade openness. The Boix logic does not hold in the case of tertiary education.

\section{Tertiary enrolment}

Finally, I shall briefly analyse the impact of government participation of social democrats on tertiary enrolment. This is necessary to determine the extent to which the expansion of spending has gone along with an expansion of access to higher education. According to the logic of the 'new politics of public investment in education', social democratic efforts in increasing public spending on tertiary education should go along with an expansion in enrolment. And, according to the results presented in Table 1, this is exactly what has happened. The cabinet share of social democrats (moving average) is positively and significantly associated with changes in gross tertiary enrolment during the 1990s (model 8). Because of better data availability, it was possible to extend the period of analysis back to 1980 (model 7). For the time period 1980-1991, the effect of social democratic government participation dilutes, loses statistical significance, and even changes sign (see also Table 5 in the online Appendix). This finding could indicate that social democrats in government have intensified their commitment to the expansion of access to public higher education only since the 1990 s. 
120

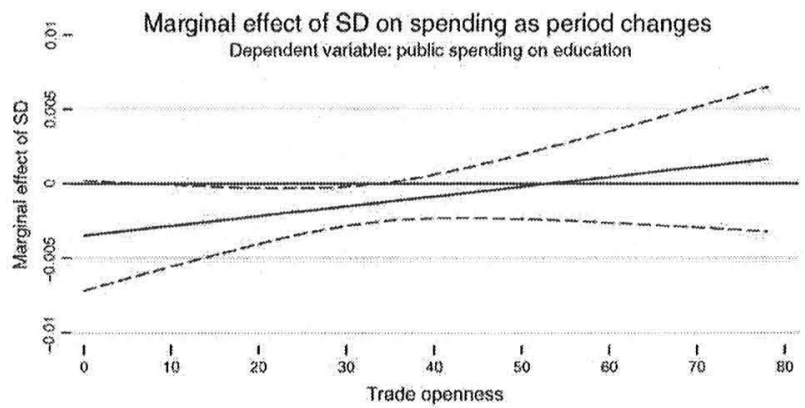

Marginal effect of SD

$95 \%$ Confidence interval

Chart A: Openness and total education spending

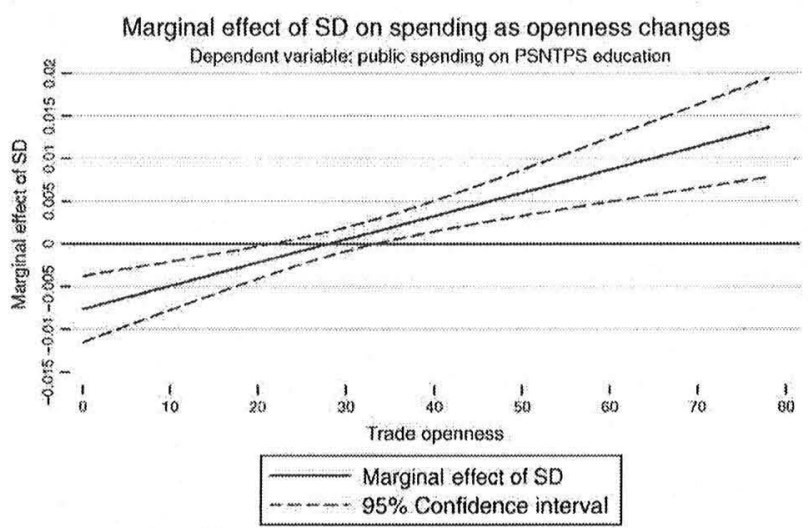

Chart B: Openness and public spending on PSNTPS education

Marginal effect of SD on spending as openness changes

s-

Dependent variable: public spending on tertiary education

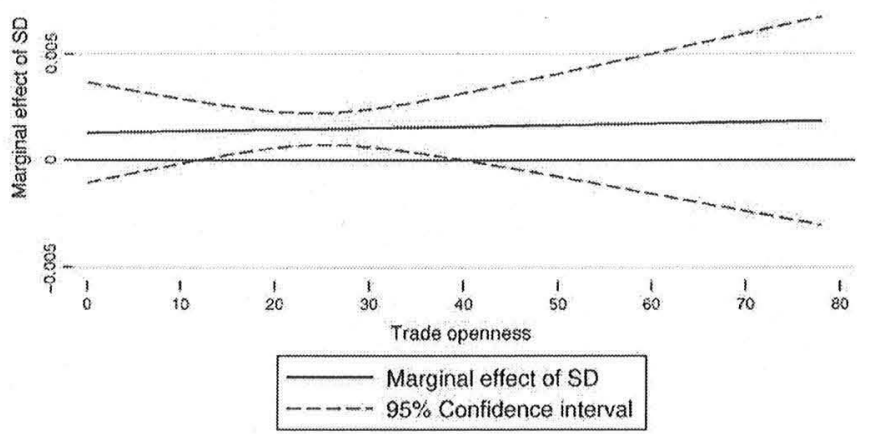

Chart C: Openness and public spending on tertiary education

Figure 1 Interaction effects between trade openness and various types of education spending

Note: $\mathrm{SD}=$ Social democrats. 
Still, one must conclude that the relationship between social democratic government participation and tertiary enrolment is not as strong as in the case of public spending. Furthermore, it is stronger in the analysis of levels of enrolment than in the analysis of changes: differences in access to higher education seem to be more resilient to change, and country differences are probably shaped more by partisan heritage than the current partisan composition of the government. In other words: leftist parties in government have expanded public spending on higher education and have also tried to increase access, but the new emphasis on tertiary education goes beyond a simple quantitative expansion; it is also part of an electoral strategy to attract new constituency groups in the middle classes.

\section{Control variables}

Without going into too much detail, a brief comment on the performance of the control variables is in order. Demographic demand, captured by the age ratio variable, is positively associated with total education spending as expected; that is, the negative coefficient estimates indicate that a higher share of young people is associated with more spending. The business cycle (levels and change of GNI per capita) has either no discernible or a negative effect on public education spending, which evidences a relative insensitivity of education to short-term fluctuations in the business cycle. Female labour force participation is associated positively with all types of education spending, as expected. The federalism dummy has a relatively weak explanatory power. The variables modelling the budget constraint (total public spending, gross public debt) were included primarily to achieve an unbiased estimate of the other independent variables of education spending. Nevertheless, their performance shows that education spending moves in line with general budget cycles. Increases in public spending are associated with increases in education spending. Rising levels of public debt, however, result in lower education spending.

\section{SUMMARY AND CONCLUSION}

This article has studied the impact of social democratic government participation on public education spending. It has been shown that partisan effects play out very differently in different educational sectors. Hence, it is necessary to analyse sectoral education spending in addition to total education spending. Second, economic internationalization is more than a diffuse background condition. The results suggest that trade openness and social democratic government participation have a joint impact on spending in the case of PSNTPS education, but not in the case of higher education. Furthermore, trade openness has an additional, separate impact on education spending, predominantly in the case of tertiary education. Third, social democrats in government have expanded access opportunities, but efforts to increase public spending have been more successful and consistent. Partly this can be explained by the resilience of 
class biases in university access, partly by the limited influence that government parties can exert on outcome indicators such as enrolment. In addition, increasing public investment in higher education serves as an instrument by means of which social democratic parties can reforge the cross-class alliance with the middle class. Since the expansion of the welfare state has come to a halt in most industrialized countries, leftist parties have to look for new ways of solving the electoral dilemma of catering to their former core constituencies and appealing to new voter groups in the middle class (Kitschelt 1994, 1999). Public investment in higher education can help to solve this dilemma.

What are the implications of the findings for partisan theory in general? First, it has clearly been shown that partisan differences continue to matter. Even controlling for a number of socio-economic and institutional variables, the partisan composition of the government continues to be an important determinant of policy outputs in terms of spending. This finding stands in contrast with the generally prevailing opinion that, in an era of retrenchment and progressing internationalization, partisan effects have lost their explanatory power with regard to short-term changes and that they remain important mostly with regard to explaining historical, cross-national differences (Castles 1998; Kittel and Obinger 2003). This article has shown that partisan differences matter, both in the short term and in the long term. Instead of arguing about the general relevance or irrelevance of partisan differences, we should engage in more concrete research into where partisan differences matter, and why they matter in some areas and not in others.

Second, partisan theory needs to be less static in building hypotheses about partisan preferences. For the sake of parsimonious models, it might be defensible to rely on 'naive' models of class politics (Boix 1998: 40). But these models have merit only as long as they produce hypotheses that can explain empirical reality. The simple class perspective, in which social democrats represent the interests of the lower classes and rightist parties are the spokespersons for upper income classes, neglects changes in the composition of the most important electoral constituencies of political parties and thus the impact of these changes on party and government policies. It also neglects the fact that political parties are more than just 'transmission belts' of socio-political demands in that they also cater to electoral constituencies out of strategic interests. In the case of higher education, social democrats are trying to cater to the interests of their core constituency by expanding access to higher education, but they are also trying to appeal to new middle-class voting groups by emphasizing education instead of other social policies. The consequence for partisan theory is that it should be more aware of the micro-level foundations of partisan preferences and the logic of party competition, without giving up its central claim: parties continue to matter.

Biographical note: Marius R. Busemeyer is a researcher at the Max Planck Institute for the Study of Societies, Köln, Germany. 
Address for correspondence: Marius R. Busemeyer, Max Planck Institute for the Study of Societies, Paulstr. 3, D-50676, Köln, Germany. email: busemeyer@mpifg.de

\section{ACKNOWLEDGEMENTS}

I would like to thank Achim Goerres, Alexander Petring, Armin Schäfer, Martin Schröder, Frieder Wolf, and Guido Tiemann for their helpful comments and suggestions. Part of this research was conducted during a research project financed by the German Research Group (DFG) under the direction of Manfred G. Schmidt. I would also like to thank the Max Planck Institute for the Study of Societies (Cologne) for providing a congenial environment in which to finish this project.

\section{NOTES}

1 Details on sources as well as descriptive statistics can be found in the online Appendix at: www.mpifg.de/people/bus.

2 The OECD distinguishes public spending on educational institutions (narrow definition of education spending) from 'total public expenditure on education' (OECD 2006: 222), which includes education-related public subsidies to households. I decided to stick with the narrow definition because, in the case of total public expenditure on education, cross-national ambiguities concerning the true classification of spending programmes remain.

3 Australia, Austria, Belgium, Canada, Denmark, Finland, France, Germany, Greece, Ireland, Italy, Japan, the Netherlands, New Zealand, Norway, Portugal, Spain, Sweden, Switzerland, the UK, the USA.

4 See the online Appendix for a justification of the use of this measure.

5 Other studies (Busemeyer 2006a, 2006b; Schmidt 2007) have shown that partisan effects had some impact in the 1980s, but that this effect disappears for the larger observation period and the 1990 s.

6 This effect is calculated by dividing the coefficient of the lagged level variable by the coefficient of the lagged dependent variable (see Iversen and Cusack 2000: 330).

7 Graphs were plotted using the STATA code provided by Brambor et al. (2006).

\section{REFERENCES}

Alt, J.E. (1985) 'Political parties, world demand, and unemployment: domestic and international sources of economic activityr', American Political Science Review 79(4): $1016-40$.

Ansell, B. (2006). 'University challenges: explaining institutional change in higher education'. Paper presented at the MPSA Conference, Chicago, April, 2006.

Ansell, B. (2008) 'Traders, teachers, and tyrants: democracy, globalization, and public investment in education', International Organization 62: 289-322.

Beck, N. (1991) 'Comparing dynamic specifications: the case of presidential approval', Political Analysis III: 51-87.

Beck, N. (2001) 'Time-series-cross-section data: what have we learned in the past few years?' Annual Review of Political Science 4: 271-93.

Beck, N. and Katz, J.N. (1995) 'What to do (and not to do) with time-series crosssection data', American Political Science Review 89(3): 634-47. 
Beck, N. and Katz, J.N. (1996) 'Nuisance vs. substance: specifying and estimating timeseries-cross-section models', Political Analysis 6: 1-36.

Boix, C. (1997) 'Political parties and the supply side of the economy: the provision of physical and human capital in advanced economies, 1960-1990', American Journal of Political Science 41(3): 814-45.

Boix, C. (1998) Political Parties, Growth and Equality: Conservative and Social Democratic Economic Strategies in the World Economy, Cambridge and New York: Cambridge University Press.

Bradley, D., Huber, E., Moller, S., Nielsen, F. and Stephens, J.D. (2003) 'Distribution and redistribution in postindustrial democracies', World Politics 55: 193-228.

Brambor, T., Clark, W.R. and Golder, M. (2006) 'Understanding interaction models: improving empirical analyses', Political Analysis 14: 63-82.

Busemeyer, M.R. (2006a) 'Der Kampf um knappe Mittel: Die Bestimmungsfaktoren der öffentlichen, privaten und sektoralen Bildungsausgaben im OECD-Länder-Vergleich', Politische Vierteljahresschrift 47(3): 393-418.

Busemeyer, M.R. (2006b) Die Bildungsausgaben der USA im internationalen Vergleich: Politische Geschichte, Debatten und Erklärungsansätze, Wiesbaden: Deutscher Universitäts-Verlag.

Busemeyer, M.R. (2007) 'Determinants of public education spending in 21 OECD democracies, 1980-2001', Journal of European Public Policy 14(4): 582-610.

Cameron, D.R. and Hofferbert, R.I. (1974) 'The impact of federalism on education finance: a comparative analysis', European Journal of Political Research 2: 225-58.

Castles, F.G. (1982) 'The impact of parties on public expenditure', in F.G. Castles (ed.), The Impact of Parties: Politics and Policies in Democratic Capitalist States, London: Sage.

Castles, F.G. (1989) 'Explaining public education expenditure in OECD nations', European Journal of Political Research 17: 431-48.

Castles, F.G. (1998) Comparative Public Policy: Patterns of Post-War Transformation, Cheltenham: Edward Elgar.

Chappell, H.W. and Keech, W.R. (1986) 'Party differences in macroeconomic policies and outcomes', American Economic Review 76(2): 71-74.

Crouch, C., Finegold, D. and Sako, M. (1999) Are Skills the Answer? The Political Economy of Skill Creation in Advanced Industrial Countries, Oxford and New York: Oxford University Press.

Cusack, T. (1997) 'Partisan politics and public finance: changes in public spending in the industrialized democracies, 1955-1989', Public Choice 91: 375-95.

Esping-Andersen, G. (1985) 'Power and distributional regimes', Politics \&́ Society 14(2): 223-56.

Esping-Andersen, G. and Korpi, W. (1984) 'Social policy as class politics in post-war capitalism: Scandinavia, Austria, and Germany', in J.H. Goldthorpe (ed.), Order and Conflict in Contemporary Politics, Oxford: Oxford University Press, pp. 179-208.

Garrett, G. (1998) Partisan Politics in the Global Economy, Cambridge and New York: Cambridge University Press.

Garrett, G. and Lange, P. (1991) 'Political responses to interdependence: what's "left" for the left?' International Organization 45(4): 539-64.

Hibbs, D.A. (1977) 'Political parties and macroeconomic policy', American Political Science Review 71: 1467-87.

Hibbs, D.A. (1987) The Political Economy of Industrial Democracies, Cambridge, MA and London: Harvard University Press.

Hicks, A. (1999) Social Democracy and Welfare Capitalism, Ithaca, NY: Cornell University Press. 
Huber, E. and Stephens, J.D. (2001) Development and Crisis of the Welfare State: Parties and Policies in Global Markets, Chicago: University of Chicago Press.

Iversen, T. (2005) Capitalism, Democracy, and Welfare, Cambridge, and New York: Cambridge University Press.

Iversen, T. (2006a) 'Class politics is dead! Long live class politics! A political economy perspective on the new partisan politics', APSA-CP Newsletter 17(2): 1-6.

Iversen, T. (2006b) 'Responses and some agenda items for the future study of democratic capitalism', Labor History 47(3): 439-49.

Iversen, T. and Cusack, T.R. (2000) 'The causes of welfare state expansion: deindustrialization or globalization?', World Politics 52: 313-49.

Iversen, T. and Soskice, D. (2001) 'An asset theory of social policy preferences', American Political Science Review 95(4): 875-93.

Kaufman, R.R. and Segura-Ubiergo, A. (2001) 'Globalization, domestic politics, and social spending in Latin America: a time-series cross-section analysis, 1973-97', World Politics 53: 553-87.

Kitschelt, H. (1994) The Transformation of European Social Democracy, Cambridge and New York: Cambridge University Press.

Kitschelt, H. (1999) 'European social democracy between political economy and electoral competition', in H. Kitschelt, P. Lange, G. Marks and J.D. Stephens (eds), Continuity and Change in Contemporary Capitalism, Cambridge and New York: Cambridge University Press, pp. 317-45.

Kittel, B. and Obinger, H. (2003) 'Political parties, institutions, and the dynamics of social expenditure in times of austerity', Journal of European Public Policy 10(1): $20-45$.

Kittel, B. and Winner, H. (2005) 'How reliable is pooled analysis in political economy? The globalization-welfare state nexus revisited', European Journal of Political Research 44: 269-93.

Nikolai, R. (2007) Die Bildungsausgaben der Schweiz im intranationalen und internationalen Vergleich, Berlin: dissertation.de

Obinger, H., Leibfried, S. and Castles, F.G. (eds) (2005) Federalism and the Welfare State: New World and European Experiences, Cambridge and New York: Cambridge University Press.

Obinger, H., Leibfried, S. and Castles, F.G. (eds) (2006) Education at a Glance: OECD Indicators 2006, Paris: OECD.

OECD (2006) Education at a Glance: OECD Indicators 2006, Paris: OECD.

Plümper, T. and Troeger, V. (2007) 'Efficient estimation of time invariant and rarely changing variables in panel data analysis with unit effects', Political Analysis 15(2): 124-39.

Plümper, T., Troeger, V. and Manow, P. (2005) 'Panel data analysis in comparative politics: linking method to theory', European Journal of Political Research 44(2): 327-54.

Schmidt, M.G. (1982) Wohlfahrtsstaatliche Politik unter bürgerlichen und sozialdemokratischen Regierungen: Ein internationaler Vergleich, Frankfurt a.M. and New York: Campus.

Schmidt, M.G. (1996) 'When parties matter: a review of the possibilities and limits of partisan influence on public policy', European Journal of Political Research 30: 155-83.

Schmidt, M.G. (2002) 'Warum Mittelmaß? Deutschlands bildungsausgaben im internationalen vergleich', Politische Vierteljahresschrift 43: 3-19.

Schmidt, M.G. (2003) 'The partisan composition of governments in OECD democracies dataset', Heidelberg: University of Heidelberg, Institute for Political Science.

Schmidt, M.G. (2007) 'Testing the retrenchment hypothesis: education spending, 1960-2002;, in F.G. Castles (ed.), The Disappearing State? Retrenchment Realities in an Age of Globalisation, Cheltenham: Edward Elgar, pp. 159-83. 
Stephens, J.D. (1979) The Transformation from Capitalism to Socialism, Urbana and Chicago: University of Illinois Press.

Thelen, K. (2004) How Institutions Evolve: The Political Economy of Skills in Germany, Britain, the United States and Japan, Cambridge and New York, Melbourne: Cambridge University Press.

UNESCO (2006) Global Education Digest 2006: Comparing Education Statistics across the World, Montreal: UNESCO Institute for Statistics.

Verner, J.G. (1979) 'Socioeconomic environment, political system, and educational policy outcomes: a comparative analysis of 102 countries', Comparative Politics 11(2): $165-87$

Wlezien, C. (1995) 'The public as thermostat: dynamics of preferences for spending', American Journal of Political Science 39(4): 981-1000.

Wlezien, C. (2004) 'Patterns of representation: dynamics of public preferences and policy', The Journal of Politics 66(1): 1-24.

Wolf, F. (2006) Die Bildungsausgaben der Bundesländer im Vergleich: Welche Faktoren erklären ihre beträchtliche Variation?, Münster: LIT. 